\title{
SISTEM PEMERINTAHAN MASYARAKAT HUKUM ADAT BADUY DALAM KERANGKA SISTEM OTONOMI DAERAH
}

\author{
1Edi Mulyadi, ${ }^{2}$ Eki Furqon \\ Fakultas Hukum, Universitas Sultan Ageng Tirtayasa, Kota Serang, Banten. \\ Correspondent email : ekifurqon@untirta.ac.id
}

$\begin{array}{lll}\mid \text { Article History } & : & \\ \mid \text { Submission } & : & \text { 23 Juli 2021 } \\ \mid \text { Last Revissions } & : & \text { 22 Desember 2021 } \\ \text { |Accepted } & : & \text { 25 Desember 2021 } \\ \text { | Copyedits Approved } & : & \text { 26 Desember 2021 }\end{array}$

\begin{abstract}
Customary law communities are the most important part of the history of the development of the Indonesian nation. The contribution given by the customary law community since ancient times has been very large for the development of human civilization, especially in the aspect of order that exists in customary law. The Baduy tribe is one of the customary law communities whose existence is still maintained to this day. The Baduy customary law community has a legal system including its government system which is the hallmark of indigenous peoples. In addition to using their customary government system, Baduy as well as part of the Unitary State of the Republic of Indonesia must participate in every national policy, especially in the area of regional and village government. The recognition given by the 1945 Constitution of the Republic of Indonesia to indigenous peoples in Indonesia is the basis for the use of their respective customary law systems. Therefore, the researcher considers it necessary to conduct a study to see how the current system of governance of the Baduy customary law community is related to the existing positive law.

The research method used is a normative juridical and empirical (mixed) juridical research method to see how the normative arrangements regarding the position of the Baduy community government system are and can describe what the government system is like. The specific target to be achieved in this research is to contribute ideas to the local government and the Baduy indigenous people in terms of the position of the Baduy customary government system in terms of the existing positive law.

The results of the research carried out explain the Baduy customary law community uses a government system that originates from their customary law known as pikukuh or karuhun. Law 23/2014 on Regional Government gives authority to provincial and district governments to regulate the empowerment of indigenous peoples and the arrangement of customary villages through existing traditional institutions. This happens because community and village empowerment is included in the mandatory concurrent government affairs that are not related to basic services.
\end{abstract}

Keywords: Baduy; Customary law; Government System; 


\section{A. PENDAHULUAN}

Indonesia adalah negara yang mempunyai sejarah panjang peradaban masyarakat hukum adat. Jauh sebelum para penjajah datang ke wilayah Nusantara (sebelum lahirnya Negara Indonesia), peradaban masyarakat saat itu sudah berada pada kondisi yang cukup maju sebagaimana majunya peradaban masyarakat adat yang tersebar di seluruh wilayah Nusantara. ${ }^{1}$ Hazairin memberikan pengertian masyarakat adat adalah sebuah kesatuan hukum, kesatuan penguasa dan kesatuan lingkungan hidup berdasarkan hak bersama atas tanah dan air bagi semua warganya. Pengertian masyarakat hukum adat juga terdapat dalam UndangUndang Nomor 39 Tahun 2014 tentang Perkebunan, pada Pasal 1 Butir (6) dijelaskan bahwa masyarakat hukum adat adalah sekelompok orang yang secara turun-temurun bermukim di wilayah geografis tertentu di Negara Kesatuan Republik Indonesia karena adanya ikatan pada asal usul leluhur, hubungan yang kuat dengan tanah, wilayah, sumber daya alam yang memiliki pranata pemerintahan adat dan tatanan hukum adat di wilayah adatnya. Berdasarkan definisi masyarakat adat diatas, dapat diartikan lebih lanjut bahwa dalam masyarakat adat kolektifitas sosial dan kelestarian tempat tinggal merupakan ciri utama yang dapat mempertahankan eksistensinya hingga saat ini. Keberadaan masyarakat adat tidak akan terlepas dari hukum yang juga hidup di dalamnya guna menjaga kestabilan adat. Hukum yang ada dalam masyarakat adat itulah yang disebut sebagai "adat" sebagaimana artinya yaitu aturan (perbuatan dan sebagainya) yang lazim diturut atau dilakukan sejak dahulu kala. ${ }^{2}$

Eksistensi masyarakat adat adalah suatu kenyataan sejarah yang tidak dapat dihindari atau disangkal oleh pemerintah. Masyarakat adat merupakan suatu segmen riil di dalam masyarakat Indonesia. Secara formal, pengakuan, penerimaan, atau pembenaran adanya masyarakat adat di dalam struktur ketatanegaraan baru diatur di dalam pasal 18 UndangUndang Dasar 1945. ${ }^{3}$ Undang-Undang Dasar Negara Republik Indonesia Tahun 1945 (UUD NRI 1945) dalam Pasal 18 B Ayat (2) telah mengakui dan menghormati kesatuan-kesatuan masyarakat hukum adat serta hak-hak tradisionalnya sepanjang masih hidup dan sesuai dengan perkembangan masyarakat dan prinsip Negara Kesatuan Republik Indonesia, yang diatur dalam undang-undang. Adanya aturan tersebut menjadi penjelas status masyarakat hukum adat yang memang sudah sejak dahulu menjadi bagian dari negara Indonesia.

Provinsi Banten memiliki salah satu masyarakat hukum adat yang masih hidup dan berkembang sampai saat ini yaitu masyarakat hukum adat Baduy/Badui (suku Baduy). Suku Baduy terletak di Kabupaten Lebak yang merupakan salah satu wilayah yang ada di Provinsi Banten. Suku Baduy memiliki jumlah penduduk sekitar 26.000 orang yang terdiri dari Baduy dalam dan Baduy luar. Sama seperti masyarakat hukum adat pada umumnya, suku Baduy juga memiliki hukum adat yang sudah hidup ditengah-tengah mereka sejak dulu. Hukum adat yang ada dalam masyarakat Baduy turut juga di dalamnya mengatur mengenai sistem pemerintahan

\footnotetext{
${ }^{1}$ Hazairin, Demokrasi Pancasila (Jakarta: Tintamas, 1970).

${ }^{2}$ https://kbbi.web.id/adat, di akses pada 21 Juni 2021.

${ }^{3}$ B Sugiswati, "Perlindungan Hukum Terhadap Eksistensi Masyarakat Adat Di Indonesia," Perspektif 17, no. 1 (2012): 31-43.
} 
adat. Sistem pemerintahan yang dimiliki masyarakat Baduy tentu berbeda dengan sistem pemerintahan khususnya sistem pemerintahan tingkat desa yang berlaku secara nasional yang diatur dalam Undang-Undang Nomor 23 Tahun 2014 tentang Pemerintahan Daerah (UU Pememerintahan Daerah) maupun Undang-Undang Nomor 6 Tahun 2014 tentang Desa (UU Desa).

Masyarakat Baduy hingga kini masih terus bertahan dari pelbagai pengaruh luar baik agama maupun teknologi pertanian yang sederhana sekalipun. Untuk bertahan mereka diikat oleh sistem pemerintahan yang bukan hanya mengatur kehidupan sosio-politik tetapi juga keagamaan. Sistem pemerintahan modern yang ditampilkan melalui pemerintahan desa memang turut mewarnai kehidupan sosio-politik mereka. ${ }^{4}$ Penolakan masyarakat baduy terhadap pengaruh luar baik dalam aspek teknologi maupun ilmu pengetahuan yang ada, membuat masyarakat baduy mau tidak mau harus bisa mengurusi semua aspek kehidupan yang ada dalam kelompoknya yang memang telah terbukti keberhasilannya karena mampu mempertahankan eksistensi suku Baduy sampai sekarang.

Masyarakat Baduy memiliki sistem pemerintahannya sendiri yang disebut pikukuh karuhun dengan tiga pemimpin adat atau yang lebih dikenal dengan istilah Puun dengan kedudukan daerah (tangtu) yang berbeda yaitu, Cibeo, Cikartawana dan Cikeusik. ${ }^{5}$ Dalam praktek kepemimpinan ketiga puun mempunyai fungsi yang berbeda sesuai dengan kedudukan dan peranannya masing-masing dalam hirarki kekerabatan. Dalam kedudukan ini Puun Cibeo berfungsi sebagai pemimpin politik yang dihubungkan oleh garis keturunan yang paling muda dan Puun Cikeusik berfungsi sebagai pemimpin agama yang ditentukan oleh garis keturunan yang paling tua, sedangkan Puun Cikartawana kedudukannya di antara kepemimpinan agama dan kepemimpinan politik. Kekuasaan agama dihubungkan dengan karuhun untuk mewujudkan identitas budaya, lain halnya kekuasaan politik dihubungkan dengan manusia untuk dapat memenuhi kebutuhan hidup duniawi. ${ }^{6}$

Berdasarkan Pasal 18 B Ayat (2) UUD NRI 1945 yang mengakui dan menghormati keberadaan masyarakat hukum adat, maka sejatinya sistem pemerintahan suku Baduy masih tetap berlaku. Meskipun demikian, perlu untuk dilakukan kajian mengenai seberapa jauh masyarakat hukum adat Baduy mampu menjaga kemurnian sistem pemerintahaan nya dalam berbagai aspek seperti dalam alur pengambilan keputusan adat, pemilihan pemimpin adat, dan kedudukannya yang hidup beriringan dengan kehidupan masyarakat modern saat ini. Berdasarkan paparan latar belakang di atas, peneliti memperoleh rumusan masalah yaitu bagaimana sistem pemerintahan masyarakat hukum adat Baduy ditinjau dari Undang-Undang Nomor 23 Tahun 2014 Tentang Pemerintahan Daerah.

\footnotetext{
${ }^{4}$ Ade Makmur K and Adi Purwanto, "Pamarentahan Baduy Di Desa Kanekes: Perspektif Kekerabatan," Jurnal Sosiohumaniora 4, no. 2 (2002): 104-15.

${ }^{5}$ Ibid.

${ }^{6}$ Ibid.
} 


\section{B. METODE PENELITIAN}

Metode penelitian yang digunakan dalam penelitian ini adalah metode penelitian hukum yuridis normatif dan metode penelitian hukum empiris (campuran). Penelitian hukum normatif meletakkan hukum sebagai sebuah bangunan sistem norma. Sistem norma yang dimaksud adalah mengenai asas-asas, norma, kaidah dari peraturan perundangan, putusan pengadilan, perjanjian serta doktrin (ajaran). ${ }^{7}$ Sedangkan metode penelitian empiris adalah penelitian lapangan, yaitu mengkaji ketentuan hukum yang berlaku serta apa yang terjadi dalam kenyataannya di masyarakat. ${ }^{8}$

Materi penelitian yang diangkat pada penelitian kali ini adalah sistem pemerintahan masyarakat hukum adat Baduy yang kemudian ditinjau dengan hukum positif yang berlaku tentang sistem pemerintahan pada tingkat desa. Penelitian ini akan melihat seperti apa sistem pemerintahan masyarakat hukum adat Baduy dan status hukum keberlakuannya saat ini dengan mengkaitkannya dengan aturan hukum yang ada. Penelitian kali ini memiliki beberapa lokasi sebagai lokasi penelitiannya yaitu:

1. Pemerintah Daerah Provinsi Banten;

2. Pemerintah Daerah Kabupaten Lebak;

3. Desa Kanekes (Baduy).

Teknik pengumpulan data yang digunakan dalam penelitian kali ini adalah studi lapangan dan studi pustaka. Jenis pengumpulan data melalui studi lapangan yang dilakukan oleh peneliti diantaranya melakukan observasi lapangan, melakukan wawancara dan kuesioner. Teknik pengumpulan data studi pustaka dilakukan peneliti dengan cara mengkaji setiap bahan hukum yang terkait topik penelitian. Analisis data yang digunakan adalah deskriptif analitis, yang mana peneliti akan menganalisa data kemudia mengolah data menjadi penjelasan secara kualitatif.

\section{HASIL DAN PEMBAHASAN}

\section{Sistem Pemerintahan Masyarakat Hukum Adat Baduy}

Masyarakat hukum adat secara pemaknaan pengertiannya memiliki keberagaman yang masing masing diantaranya dipengaruhi oleh latar belakang dan batasan konsepsi berbeda. Salah satu lembaga masyarakat yang bergerak di bidang kebudayaan dan adat Aliansi Masyarakat Adat Nusantara (AMAN) memberikan definisi masyarakat adat sebagai suatu komunitas yang memiliki asal-usul leluhur secara turuntemurun di wilayah geografis tertentu, serta memiliki nilai, ideologi, ekonomi, politik, budaya, dan sistem sosial yang khas. ${ }^{9}$ Istilah penyebutan masyarkat

\footnotetext{
${ }^{7}$ Mukti Fajar and Yulianto Achmad, Dualisme Penelitian Hukum Normatif Dan Empiris (Yogyakarta: Pustaka Pelajar, 2010).

${ }^{8}$ Suharsimi Arikunto, Prosedur Penelitian Suatu Pendekatan Praktek (Jakarta: Rineka Cipta, 2002).

${ }^{9}$ Nyoman Shuida, Masyarakat Adat Dalam Pusaran Perubahan (Jakarta: Kemenko Bidang Pembangunan Manusia \& Kebudayaan, 2016).
} 
hukum adat sendiri dalam beragam peraturan perundang-undangan di Indonesia memiliki perbedaan antara satu dengan yang lainnya.

Ketentuan UUD NRI 1945 sebagai kontsitusi negara Indonesia pada Pasal 18B ayat (2) menuliskan istilah "kesatuan masyarakat hukum adat" untuk mengidentifikasi masyarakat adat yang ada di Indonesia. Berbeda dengan Pasal 18B ayat (2), pada Pasal 28I ayat (3) dituliskan istilah "masyarakat tradisional" untuk mengidentifikasi hal yang sama yaitu masyarakat hukum adat. Meskipun diantara kedua pasal dalam satu peraturan tersebut menuliskan dua istilah yang berbeda, namun perbedaan diantaranya hanya terletak pada kriteria untuk dapat tergolong masuk dalam istilah tersebut.

Berkaitan dengan UU Nomor 23 Tahun 2014 tentang Pemerintahan Daerah, istilah yang digunakan adalah "masyarakat hukum adat". Sementara UU Nomor 6 Tahun 2014 tentang Desa menyebutkan istilah "Desa Adat", namun pengertian mengenai desa adat itu sendiri disamakan dengan pengertian Desa secara umum, yaitu Desa adalah desa dan desa adat atau yang disebut dengan nama lain, selanjutnya disebut Desa, adalah kesatuan masyarakat hukum yang memiliki batas wilayah yang berwenang untuk mengatur dan mengurus urusan pemerintahan, kepentingan masyarakat setempat berdasarkan prakarsa masyarakat, hak asal usul, dan/atau hak tradisional yang diakui dan dihormati dalam sistem pemerintahan Negara Kesatuan Republik Indonesia. ${ }^{10}$

Memperhatikan ketentuan dalam UU Nomor 17 Tahun 2019 tentang Sumber Daya Air menyebutkan istilah "masyarakat adat" yang memiliki arti adalah masyarakat hukum adat dan/atau masyarakat tradisional yang hidup secara turuntemurun di wilayah geografis tertentu dan diikat oleh identitas budaya, hubungan yang kuat dengan tanah, serta wilayah dan sumber daya alam di wilayah adatnya. ${ }^{11}$ Selain itu dalam UU Nomor 32 Tahun 2009 tentang Perlindungan dan Pengelolaan Lingkungan Hidup dijelaskan bahwa Masyarakat Hukum Adat adalah kelompok masyarakat yang secara turun temurun bermukim diwilayah geografis tertentu karena adanya ikatan pada asal usul leluhur, adanya hubungan yang kuat dengan lingkungan hidup, serta adanya sistem nilai yang menentukan pranata ekonomi, politik, sosial, dan hukum. ${ }^{12}$ Dalam UU Nomor 18 Tahun 2004 tentang Perkebunan dijelaskan kriteria Masyarakat Hukum Adat, yaitu : (1) Masyarakat yang masih hidup dalam paguyuban; (2) Memiliki kelembagaan dalam bentuk perangkat adat; (3) Memiliki wilayah hukum adat yang jelas; (4) memiliki pranata hukum, khususnya peradilan adat yang masih ditaati; (5) adanya pengukuhan dengan peraturan daerah. ${ }^{13}$

Masyarakat hukum adat baduy "Masyarakat Baduy" atau "Masyarakat Rawayan" adalah sekelompok masyarakat Sunda yang masih mempertahankan gaya hidup tradisional dan mengisolasi diri dari kehidupan modern, segala sesuatunya

\footnotetext{
${ }^{10}$ Lihat Pasal 1 Angka 1 Undang-Undang Nomor 6 Tahun 2014 tentang Desa.

${ }^{11}$ Lihat Pasal 1 angka 22 Undang-Undang Nomor 17 Tahun 2019 tentang Sumber Daya Air.

12 Lihat Pasal 1 angka 31 Undang-Undang Nomor 32 Tahun 2009 tentang Perlindungan dan Pengelolaan Lingkungan Hidup.

${ }^{13}$ Lihat Penjelasan Pasal 9 ayat (2) Undang-Undang Nomor 18 Tahun 2004 tentang Perkebunan.
} 
dilakukan dengan menggunakan aturan adat. Lokasi tempat tinggal masyarakat hukum adat Baduy terletak di Desa Kanekes, Kecamatan Leuwidamar, Kabupaten Lebak, Provinsi Banten. Hak ulayat ${ }^{14}$ masyarakat hukum adat baduy dibatasi terhadap tanahtanah di wilayah Desa Kanekes Kecamatan Leuwidamar Kabupaten Lebak ${ }^{15}$

Istilah Baduy sendiri berasal dari nama tempat yang diambil dari nama sungai Cibaduy. Orang-orang yang menetap di sekitar wilayah itu dikenal dengan nama orang Baduy, selain itu istilah Baduy juga berasal dari nama pohon yang hanya terdapat di kampung itu yaitu pohon Baduyut, yang kemudian juga dijadikan nama untuk menyebut orangorang yang tinggal di sekitar pohon-pohon itu tumbuh. ${ }^{16}$ Keterangan lain menyebutkan bahwa kata Baduy berasal dari kata Budha, yaitu agama yang dianut oleh Prabu Siliwangi dan rakyat dari Kerajaan Padjadjaran, hal ini sejalan dengan sumber yang mengatakan bahwa asal muasal masyarakat Baduy adalah berasal dari masyarakat para punggawa Kerajaan Padjadjaran (sekitar abad XVI) yang melarikan diri dari kerjaaan, karena masuknya agama Islam ke wilayah Banten melalui Pantai utara Cirebon. Kemudian mereka melarikan ke daerah Banten selatan, di wilayah Pegunungan Kendeng. ${ }^{17}$

Masyarakat Baduy terbagi ke dalam kelompok masyarakat Baduy Dalam dan masyarakat Baduy Luar, hal mendasar yang membedakan keduanya terletak pada ketaatan terhadap aturan adat, hal itu tampak dari cara berpakain dan keterbukaan terhadap kehidupan modern. ${ }^{18}$ Masyarakat Baduy dalam menempati sekitar $30 \%$ wilayah Baduy, terdiri dari tiga kampung, yaitu Cibeo, Cikatarwana dan Cikeusik. Baduy luar memiliki sekitar 49 kampung yang menempati areal sisanya yang langsung berbatasan dengan dunia luar. Selain kampung-kampung tersebut terdapat wilayah yang disebut Babakan dan Tanah Dangka. ${ }^{19}$

Masyarakat Baduy Dalam sangat ketat dalam menjalankan setiap aturan adat, sehingga hal-hal yang baerbau modern sangat dihindari, dari segi pakain mereka biasa menggunakan pakaian putih dengan ikat kepala warna senada, berbeda dengan masyarakat Baduy Luar yang biasa menggunakan pakaian warna hitam dan ikat kepala

\footnotetext{
${ }^{14}$ Hak Ulayat adalah kewenangan yang menurut hukum adat dipunyai oleh masyarakat hukum adat tertentu atas wilayah tertentu yang merupakan lingkungan hidup para warganya untuk mengambil manfaat dari sumber daya alam, termasuk tanah, dalam wilayah tersebut, bagi kelangsungan hidup dan kehidupannya, yang timbul dari hubungan secara lahiriah dan batiniah turun temurun dan tidak terputus antara masyarakat hukum adat tersebut dengan wilayah yang bersangkutan.

${ }^{15}$ Lihat Pasal 2 Peraturan Daerah Kabupaten Lebak Nomor 32 Tahun 2001 tentang Perlindungan Atas Hak Ulayat Masyarakat Baduy.

${ }^{16}$ Nandang Rusnandar, Seba Dalam Tradisi Masyarakat Baduy Di Banten (Bandung: Badan Pelestarian Nilai Budaya, 2012).

${ }^{17}$ Ibid.

${ }^{18}$ Dinas Lingkungan Hidup dan Kehutanan Provinsi Banten, "Profil Masyarakat Hukum Adat Dan Kearifan Lokal Di Provinsi Banten (Kajian Kearifan Lokal Dalam Pelestarian Lingkungan Hidup Dan Hutan)” (Serang, 2017).

19 Muhlisin, Helmy Faizi Bahrul Ulumi, and Ayatullah Humaeni, "Kebijakan Pemerintah Daerah Dalam Perlindungan Masyarakat Adat Di Provinsi Banten: Studi Kasus Masyarakat Adat Baduy Dan Citorek," Jurnal Kebijakan Pembangunan Daerah 1, no. 1 (2017): 27-44.
} 
warna biru motif batik Baduy. Masyarakat Baduy Luar sudah cukup terbuka dengan mulai mengenal perangkat teknologi komunikasi yaitu telefon genggam (hand phone).

Masyarakat hukum adat Baduy memiliki stratifikasi sosial atau pelapisan masyarakat berdasarkan status atau tingkatan tertentu sesuai kesepakatan. Pelapisan ini didasarkan pada sataus wilayah kemandalaan (tanah suci) Kanekes. Kemandalaan Kanekes terbagi menjadi tiga lokasi pemukiman (1) Wilayah Tangtu yang dikenal dengan Baduy Kajeroan atau Baduy Jero; (2) Wilayah Panamping, dikenal dengan sebutan Panamping; dan (3) Wilayah Dangka, yakni kampung yang dianggap dibawah keterikatan secara adat dengan orang Baduy yang mempunyai wewenang kemandalaan secara penuh. ${ }^{20}$

Masyarakat hukum adat Baduy yang berada pada wilayah Desa Kanekes dipimpin oleh tiga puun, yakni Puun Cikeusik, Puun Cibeo, dan Puun Cikartawana. Orientasi atau kegiatan para puun merujuk pada pikukuh karuhun. Pikukuh merupakan ketentuan adat mutlak, sedangkan karuhun adalah para arwah nenek moyang. Pikukuh karuhun bertujuan untuk mensejahterakan kehidupan masyarakat Baduy dan dunia ramai. Mensejahterakan dunia dengan prinsip tanpa perubahan apapaun, yaitu melalui: (1) ngabaratapakeun (melakukan tapa terhadap inti jagat dan dunia); (2) ngareremokeun (menghormati dengan cara menjodohkan Dewi Padi/Sanghyang Asri dengan bumi); dan mengekalkan pikukuh dengan melaksanakan semua ketentuan yang ada. $^{21}$

Proses menjalankan pemerintahan adat, ketiga puun memiliki tugas dan wewenang berbeda. Kapuunan Cikeusik bertugas mengurusi bidang keagamaan dan pengadilan adat, terutama dalam menentukan waktu pelaksanaan upacara-upacara adat (seren tahun, kawalu dan seba) dan memutuskan hukuman bagi para pelanggar adat. Kapuunan Cibeo berwenang mengurusi bidang pelayanan kepada warga dan tamu di kawasan Kanekes, termasuk terkait ketertiban wilayah, pelintas batas dan berhubungan dengan daerah luar. Kapuunan Cikartawana berwenang mengurusi bidang pembinaan warga, kesejahteraan, keamanan dan monitoring yang berhubungan denga Kanekes. Dalam lembaga Ka-puun-an, puun dibantu oleh Girang Seurat ('sekretaris' puun atau pemangku adat), Baresan (petugas keamanan kampung), Jaro (pelaksana harian urusan pemerintahan kapuunan), dan Palawari ('panitia tetap' dalam berbagai kegiatan upacara adat). ${ }^{22}$

Seperti sudah dijelaskan di awal, bahwa Masyarakat Kanekes dipimpin oleh Puun (ketua adat). Ada tiga puun yang memimpin masyarakat Kanekes, yaitu Puun Cikeusik, Puun Cikartawana, dan Puun Cibeo. Di bawah ini adalah pembagian tugas atau wewenang para puun beserta para pembantu pelaksana kelembagaan adat dalam menjalankan pemerintahan adatnya. ${ }^{23}$

\footnotetext{
${ }^{20}$ Rusnandar, Op.cit.

${ }^{21}$ Imam Hanafi, Nyorenag Alam Ka Tukang. Nyawang Anu Bakal Datang (Bogor: RMI - The Indonesian Institute for Forest and Environment., 2014).

${ }^{22}$ Ibid.

${ }^{23}$ Ibid.
} 
Tabel 1

(Kepemimpinan Desa Kanekes)

\begin{tabular}{|c|c|}
\hline $\begin{array}{c}\text { Jabatan } \\
\text { Kapuunan }\end{array}$ & Tugas / Wewenang \\
\hline Puun Cikeusik & $\begin{array}{l}\text { Mengurusi bidang keagamaan, pengadilan adat, menentukan } \\
\text { pelaksanaan (seren taun, kawalu dan seba), menentukan hukamn } \\
\text { bagi para pelangar adat. }\end{array}$ \\
\hline Puun Cibeo & $\begin{array}{l}\text { Mengurusi bidang pelayanan kepada warga dan tamu di kawasan } \\
\text { Kanekes, administratur tertib wilayah, batas wilayah dan hal yang } \\
\text { berhubungan dengan daerah luar. }\end{array}$ \\
\hline $\begin{array}{l}\text { Puun } \\
\text { Cikartawana }\end{array}$ & $\begin{array}{l}\text { Mengurusi bidang pembinaan warga, kesejahteraan, keamanan dan } \\
\text { monitoring kawasan Kanekes. }\end{array}$ \\
\hline Girang Seurat & sekretaris puun \\
\hline Baresan & Petugas keamana kampung \\
\hline $\begin{array}{l}\text { Jaro } \\
\text { Pamarentah }\end{array}$ & $\begin{array}{l}\text { Pelaksana harian urusan pemerintah Kapuunan, penghubung antara } \\
\text { unsur pemerintahan (Camat, Bupati, dll) dengan masyarakat } \\
\text { Kanekes. }\end{array}$ \\
\hline Tangkesan & $\begin{array}{l}\text { (Dukun kepala), bertanggung jawab mengenai masalah kesehatan } \\
\text { warga Kanekes }\end{array}$ \\
\hline Palawari & Panitia tetap untuk mengurusi berbagai kegiatan upacara adat \\
\hline
\end{tabular}

Desa Kanekes yang telah ditetapkan menjadi desa adat sudah tentu memiliki perbedaan dalam hal pemerintahan desa dengan desa-desa lain pada umumnya. Terdapat perbedaan dalam beberapa aspek, diantaranya : ${ }^{24}$

1. Kepala Desa Kanekes (Jaro Pamarentah), bukan dipilih oleh rakyat, melainkan diangkat dan ditunjuk langsung pemerintah atas persetujuan Puun ;

2. Kepala Desa hanya dibantu oleh Carik Desa, Pangiwa, dan Kokolot (tidak ada LKMD atu aparatur pembantu pemerintah desa);

3. Kepala Desa tidak disyaratakan harus pandai baca-tulis, karena dalam adat masyarakat Baduy, baca-tulis adalah buyut (tabu);

4. Desa Kanekes tidak memiliki kantor, yang menjadi kantor adalah rumah Jaro Pamarentah itu sendiri.

\footnotetext{
${ }^{24}$ Rusnandar, Op.cit.
} 
Perbedaan-perbedaan tersebut dikarenakan dasar hukum yang digunakan dalam setiap aspek pemerintahan itu berbeda, jika pada desa biasa menggunakan peraturan perundang-undangan sebagaimana termuat pada UU Pemerintahan Daerah maupun UU Desa sebagai dasarnya, desa adat hanya menggunakan hukum adat yang berlaku di dalamnya sepanjang tidak bertentangan dengan prinsip Negara Kesatuan Republik Indonesia.

\section{Relevansi Sistem Pemerintahan Adat dengan Sistem Pemerintahan Daerah}

Secara konstitusional masyarakat hukum adat di Indonesia telah dijamin keberadaannya oleh Pasal 18B Ayat (2) Undang-Undang Dasar Negara Republik Indonesia yang menyatakan bahwa negara mengakui dan menghormati kesatuankesatuan masyarakat hukum adat serta hak-hak tradisionalnya sepanjang masih hidup dan sesuai dengan perkembangan masyarakat dan prinsip Negara Kesatuan Republik Indonesia, yang diatur dalam undang-undang. Lebih lanjut, segala peraturan umum tentang pemerintahan di daerah yang dibuat oleh pemerintah tidak bisa serta merta diberlakukan terhadap masyarakat hukum adat yang ada di Indonesia karena kekhususannya. Oleh karena itu perlu adanya penyesuaian tertentu untuk dapat mengakomodir keberlangsungan dari masyarkat hukum adat yang ada.

Sementara itu, sebagaimana disebutkan dalam Pasal 28I ayat (3) UUD 1945, "Identitas budaya dan hak masyarakat tradisional dihormati selaras dengan perkembangan zaman dan peradaban." Pernyataan-pernyataan tersebut merupakan ketetapan resmi yang memperlihatkan bahwa tidak satupun kelompok Masyarakat Adat yang dilupakan atau boleh tertinggal dalam proses pembangunan. Berkenaan dengan hal tersebut, Indonesia terikat pada komitmen internasional tentang pengakuan hak-hak Masyarakat Adat. Pada 13 September 2007 Pemerintah Indonesia ikut menandatangani deklarasi United Nation Declaration on The Rights of Indigenous Peoples (UNDRIP) yang mengamanatkan bahwa Masyarakat Adat memiliki hak yang sama terkait penghidupan, pendidikan, mempertahankan identitas, dan bebas dari segala bentuk diskriminasi.

Berdasarkan Pasal 1 Angka (4) dalm UU Nomor 23 Tahun 2014 tentang Pemerintahan Daerah, secara keseluruhan pengertian desa adalah desa dan desa adat atau yang disebut dengan nama lain, adalah kesatuan masyarakat hukum yang memiliki batas wilayah yang berwenang untuk mengatur dan mengurus urusan pemerintahan, kepentingan masyarakat setempat berdasarkan prakarsa masyarakat, hak asal usul, dan/atau hak tradisional yang diakui dan dihormati dalam sistem pemerintahan Negara Kesatuan Republik Indonesia. ${ }^{25}$

Penyebutan desa adat dalam UU Pemerintahan Daerah disamakan dengan istilah desa secara umum. Hal ini berkaitan dengan pembagian wilayah negara sebagaimana terdapat dalam Pasal 2 ayat (1) dan (2) UU Pemerintahan Daerah yang menjelaskan bahwa Negara Kesatuan Republik Indonesia dibagi atas daerah provinsi dan daerah

${ }^{25}$ Lihat Pasal 1 Angka (43) Undang-Undang Nomor 23 Tahun 2014 Tentang Pemerintahan Daerah. 
provinsi itu dibagi atas daerah kabupaten dan kota, daerah kabupaten/kota dibagi atas kecamatan dan kecamatan dibagi atas kelurahan dan/atau desa.

Tabel 2

(Pembagian Urusan Pemerintahan Bidang Pemberdayaan Masyarakat Dan Desa berdasarkan Lampiran UU Nomor 23 Tahun 2014 tentang Pemerintahan Daerah)

\begin{tabular}{|c|c|c|c|c|}
\hline NO & SUB URUSAN & $\begin{array}{c}\text { PEMERINTAH } \\
\text { PUSAT }\end{array}$ & $\begin{array}{c}\text { DAERAH } \\
\text { PROVINSI }\end{array}$ & $\begin{array}{c}\text { DAERAH } \\
\text { KABUPATEN/KOTA }\end{array}$ \\
\hline 1. & Penataan Desa & 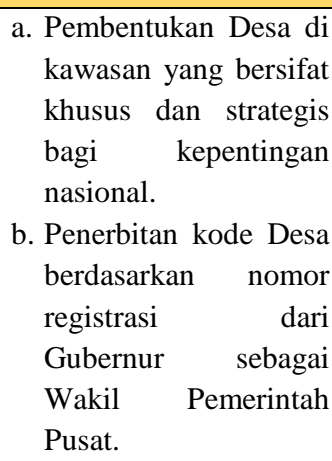 & $\begin{array}{l}\text { Penetapan susunan } \\
\text { kelembagaan, } \\
\text { pengisian } \\
\text { jabatan, dan masa } \\
\text { jabatan } \\
\text { kepala desa adat } \\
\text { berdasarkan hukum } \\
\text { adat. }\end{array}$ & $\begin{array}{l}\text { Penyelenggaraan penataan } \\
\text { Desa. }\end{array}$ \\
\hline 2. & Kerja sama desa & $\begin{array}{l}\text { Fasilitasi kerja sama } \\
\text { antar- } \\
\text { Desa dari Daerah } \\
\text { provinsi } \\
\text { yang berbeda. }\end{array}$ & $\begin{array}{l}\text { Fasilitasi kerja sama } \\
\text { antar- } \\
\text { Desa dari Daerah } \\
\text { kabupaten/kota yang } \\
\text { berbeda } \\
\text { dalam } 1 \quad \text { (satu) } \\
\text { Daerah } \\
\text { provinsi. }\end{array}$ & $\begin{array}{l}\text { Fasilitasi kerja sama antar- } \\
\text { Desa dalam } 1 \text { (satu) Daerah } \\
\text { kabupaten/kota. }\end{array}$ \\
\hline 3. & $\begin{array}{l}\text { Administrasi } \\
\text { Pemerintahan Desa }\end{array}$ & & & $\begin{array}{l}\text { Pembinaan dan pengawasan } \\
\text { penyelenggaraan } \\
\text { administrasi pemerintahan } \\
\text { Desa. }\end{array}$ \\
\hline 4. & $\begin{array}{l}\text { Kemasyarakatan, } \\
\text { Lembaga Adat, dan } \\
\text { Masyarakat Hukum } \\
\text { Adat }\end{array}$ & $\begin{array}{l}\text { Pemberdayaan } \\
\text { lembaga } \\
\text { kemasyarakatan yang } \\
\text { bergerak di bidang } \\
\text { pemberdayaan Desa } \\
\text { tingkat } \\
\text { nasional. }\end{array}$ & $\begin{array}{l}\text { Pemberdayaan } \\
\text { lembaga } \\
\text { kemasyarakatan } \\
\text { yang } \\
\text { bergerak di bidang } \\
\text { pemberdayaan Desa } \\
\text { dan } \\
\text { lembaga adat tingkat } \\
\text { Daerah serta } \\
\text { provinsi } \\
\text { pemberdayaan } \\
\text { masyarakat hukum } \\
\text { adat } \\
\text { yang masyarakat } \\
\text { pelakunya } \\
\text { hukum adat yang } \\
\text { sama dintas } \\
\text { berada di liah } \\
\text { Daerah } \\
\text { kabupaten/kota. }\end{array}$ & $\begin{array}{l}\text { a. Pemberdayaan lembaga } \\
\text { kemasyarakatan yang } \\
\text { bergerak di bidang } \\
\text { pemberdayaan Desa dan } \\
\text { lembaga adat tingkat } \\
\text { Daerah kabupaten/kota } \\
\text { dan pemberdayaan } \\
\text { masyarakat hukum adat } \\
\text { yang masyarakat } \\
\text { pelakunya hukum adat } \\
\text { yang sama dalam Daerah } \\
\text { kabupaten/kota. } \\
\text { b. Pemberdayaan lembaga } \\
\text { kemasyarakatan dan } \\
\text { lembaga adat tingkat } \\
\text { Desa. }\end{array}$ \\
\hline
\end{tabular}


Pemberdayaan masyarakat dan desa yang termasuk di dalamnya mengenai masyarakat hukum adat termasuk kedalam urusan pemerintahan konkuren (urusan pemerintahan yang dibagi antara pemerintah pusat dan daerah provinsi dan daerah kabupaten/kota) yang termasuk kedalam urusan pemerintahan wajib yang tidak berkaitan dengan pelayanan dasar. ${ }^{26}$

Berdasarkan Tabel 2 di atas, yang berkaitan dengan penataan desa, pemerintah daerah provinsi memiliki tugas untuk menetapkan susunan kelembagaan, pengisian jabatan, dan masa jabatan kepala desa adat berdasarkan hukum adat. ${ }^{27}$ Hal tersebut memberikan legalitas pada norma-norma hukum adat yang berlaku di masyarakat hukum adat baik yang berurusan mengenai kelembagaan adat maupun mengenai hukum pemerintahan nya. Dalam hal pemerintahan masyarakat hukum adat Baduy, Pemerintah Daerah Provinsi Banten lah yang bertugas untuk menetapkan susunan kelembagaan, pengisian jabatan, dan masa jabatan kepala desa masyarakat hukum adat Baduy, tentu dengan berdasarkan hukum adat yang berlaku.

Pemerintah Kabupaten Lebak sebagai induk daerah dari masyarakat hukum adat Baduy telah memberikan kekhususan juga terhadap masyarakat hukum adat Baduy melalui Peraturan Daerah Kabupaten Lebak Nomor 1 Tahun 2015 tentang Desa. Desa adat yang dalam hal ini masyarakat hukum adat Baduy, memiliki kewenangan berdasarkan hak asal usul meliputi: ${ }^{28}$

1) pengaturan dan pelaksanaan pemerintahan berdasarkan susunan asli;

2) pengaturan dan pengurusan ulayat atau wilayah adat;

3) pelestarian nilai sosial budaya Desa Adat;

4) penyelesaian sengketa adat berdasarkan hukum adat yang berlaku di Desa Adat dalam wilayah yang selaras dengan prinsip hak asasi manusia dengan mengutamakan penyelesaian secara musyawarah;

5) penyelenggaraan sidang perdamaian peradilan Desa Adat sesuai dengan ketentuan peraturan perundang-undangan;

6) pemeliharaan ketenteraman dan ketertiban masyarakat Desa Adat berdasarkan hukum adat yang berlaku di Desa Adat; dan

7) pengembangan kehidupan hukum adat sesuai dengan kondisi sosial budaya masyarakat Desa Adat.

Pelaksanaan kewenangan di atas tersebut dan pelaksanaan kewenangan penugasan dari pemerintah daerah kepada desa adat meliputi penyelenggaraan pemerintahan desa adat, pelaksanaan pembangunan desa adat, pembinaan kemasyarakatan desa adat, dan pemberdayaan masyarakat desa adat, diurus oleh desa adat. Pengaturan dan penyelenggaraan pemerintahan desa adat dilaksanakan sesuai dengan hak asal usul dan hukum adat yang berlaku di desa adat yang masih hidup serta sesuai dengan perkembangan masyarakat dan tidak bertentangan dengan asas

\footnotetext{
${ }^{26}$ Lihat Pasal 12 Undang-Undang Nomor 23 Tahun 2014 Tentang Pemerintahan Daerah.

${ }^{27}$ Lampiran Undang-Undang Nomor 23 Tahun 2014 Tentang Pemerintahan Daerah Huruf (M) Pembagian Urusan Pemerintahan Bidang Pemberdayaan Masyarakat Dan Desa.

${ }^{28}$ Lihat Pasal 215 Peraturan Daerah Kabupaten Lebak Nomor 5 Tahun 2015 tentang Desa.
} 
penyelenggaraan pemerintahan desa adat dalam prinsip Negara Kesatuan Republik Indonesia. Pemerintahan desa adat menyelenggarakan fungsi per musyawaratan dan musyawarah desa adat sesuai dengan susunan asli desa adat atau dibentuk baru sesuai dengan prakarsa masyarakat desa adat. Mengenai susunan kelembagaan, pengisian jabatan, dan masa jabatan kepala desa adat berdasarkan hukum adat ditetapkan dalam peraturan daerah provinsi. Dihubungkan dengan sistem pemerintahan masyarakat hukum adat Baduy saat ini, maka dapat dilihat bahwa keberadaan dan eksistensi masyarakat hukum adat Baduy merupakan dampak dari adanya pengakuan terhadap hukum adat di Indonesia.

\section{KESIMPULAN}

Masyarakat hukum adat Baduy yang berada di wilayah Desa Kanekes menggunakan sistem pemerintahan yang berdasar pada hukum adatnya yang dikenal dengan istilah pikukuh karuhun dengan tiga puun atau pemimpin adat dengan kedudukan daerah (tangtu) yang berbeda yaitu, Cibeo, Cikartawana dan Cikeusik. Pada masyarakat hukum adat Baduy hanya menggunakan pranata kelembagaan adat sebagai sarana penyelenggaraan pemerintahan desa. Pemerintah daerah provinsi dan pemerintah daerah kabupaten adalah pelaksana urusan pemerintah pusat di daerah dalam hal menangani urusan pemberdayaan masyarakat dan desa. Dalam hal masyarakat hukum adat Baduy, Pemerintah Kabupaten Lebak mempunyai tugas untuk melakukan penyelenggaraan penataan desa termasuk membentuk aturan khusus mengenai masyarakat hukum adat Baduy. Pemerintah daerah Provinsi Banten maupun Pemerintah Daerah Kabupaten Lebak harus lebih mengoptimalkan potensi yang dimiliki masyarakat hukum adat baduy terutama melalui pembentukan peraturan-peraturan yang mampu memberikan keleluasaan masyarakat baduy dalam hal sistem pemerintahannya, sebagai wujud penghargaan kepada masyarakat adat yang diakui keberadaannya oleh konstitusi.

\section{Buku \& Jurnal :}

\section{DAFTAR PUSTAKA}

Arikunto, Suharsimi. Prosedur Penelitian Suatu Pendekatan Praktek. Jakarta: Rineka Cipta, 2002.

Dinas Lingkungan Hidup dan Kehutanan Provinsi Banten. "Profil Masyarakat Hukum Adat Dan Kearifan Lokal Di Provinsi Banten (Kajian Kearifan Lokal Dalam Pelestarian Lingkungan Hidup Dan Hutan).” Serang, 2017.

Fajar, Mukti, and Yulianto Achmad. Dualisme Penelitian Hukum Normatif Dan Empiris. Yogyakarta: Pustaka Pelajar, 2010.

Hanafi, Imam. Nyorenag Alam Ka Tukang. Nyawang Anu Bakal Datang. Bogor: RMI The Indonesian Institute for Forest and Environment., 2014.

Hazairin. Demokrasi Pancasila. Jakarta: Tintamas, 1970.

Makmur K, Ade, and Adi Purwanto. "Pamarentahan Baduy Di Desa Kanekes: Perspektif 
Kekerabatan.” Jurnal Sosiohumaniora 4, no. 2 (2002): 104-15.

Muhlisin, Helmy Faizi Bahrul Ulumi, and Ayatullah Humaeni. "Kebijakan Pemerintah Daerah Dalam Perlindungan Masyarakat Adat Di Provinsi Banten: Studi Kasus Masyarakat Adat Baduy Dan Citorek." Jurnal Kebijakan Pembangunan Daerah 1, no. 1 (2017): 27-44.

Rusnandar, Nandang. Seba Dalam Tradisi Masyarakat Baduy Di Banten. Bandung: Badan Pelestarian Nilai Budaya, 2012.

Shuida, Nyoman. Masyarakat Adat Dalam Pusaran Perubahan. Jakarta: Kemenko Bidang Pembangunan Manusia \& Kebudayaan, 2016.

Sugiswati, B. "Perlindungan Hukum Terhadap Eksistensi Masyarakat Adat Di Indonesia." Perspektif 17, no. 1 (2012): 31-43.

\section{Peraturan Perundang-Undangan :}

Undang-Undang Dasar Negara Republik Indonesia Tahun 1945;

Undang-Undang Nomor 6 Tahun 2014 tentang Desa;

Undang-Undang Nomor 23 Tahun 2014 tentang Pemerintahan Daerah;

Undang-Undang Nomor 32 Tahun 2009 tentang Perlindungan dan Pengelolaan Lingkungan Hidup

Peraturan Daerah Kabupaten Lebak Nomor 5 Tahun 2015 tentang Desa. 
AJUDIKASI : Jurnal Ilmu Hukum, Volume 5 Nomor 2, Desember 2021. Hlm. 165-178

P-ISSN 2613-9995 \& E-ISSN 2614-0179 